\title{
ANALISIS BEBAN KERJA UNTUK MENENTUKAN JUMLAH KARYAWAN OPTIMAL PADA BAGIAN OPERASI SARANA PENYELENGGARAAN DIKLAT KILANG PPSDM MIGAS
}

\author{
${ }^{1}$ Edi Hartono, ${ }^{2}$ Muh. Hisjam \\ 1,2 Jurusan Teknik Industri, Fakultas Teknik, Universitas Sebelas Maret Surakarta \\ Jl. Ir. Sutami No.36 A, Pucangsawit, Jebres, Kota Surakarta, Jawa Tengah 57126 \\ e-mail: edihart@student.uns.ac.id
}

\begin{abstract}
PPSDM Migas is a company engaged in oil and gas. One factor that must be considered by the company is the distribution of workload to employees so that the effectiveness and efficiency of employees can be reach. The fact in the field, PPSDM Migas has just transferred its employees to PPSDM Jakarta, so there is a discrepancy between workload and number of employees. To overcome the problem of measuring workloads in PPSDM Migas, this study uses a task per task approach. This method will provide information about the allocation of employee human resources to complete the existing workload optimally. Based on the results of the workload measurement on PPSDM Migas using the task per task approach it can be concluded that from the two positions as a pilot project there was one position which resulted in a mismatch between the workload and the number of office holders, namely 4 Tank employees and Distribution but from the calculation results it takes 7 employees. The position of Executor of Distillation Operations has the number of employees as many as 2 employees and from the results of the calculation required 2 employees, this shows the suitability between the number of employees and the workload on the position. Based on the results of calculations from both positions, the position of Implementing Distillation Operations is included in the category of sufficient office efficiency. Whereas in the position of Implementing Tank and Distribution Installation get the medium category.
\end{abstract}

Key words : Workload Analysis; optimal number of workers; task per task approach

\begin{abstract}
Abstrak
PPSDM Migas adalah perusahan yang bergerak di bidang minyak dan ga. Salah satu faktor yang harus diperhatikan adalah pembagian beban kerja kepada karyawan sehingga efektifitas dan efisiensi karyawan dapat optimal untuk perusahaan. Fakta dilapangan PPSDM Migas baru saja melakukan mutasi para pekerjanya ke PPSDM Jakarta, sehingga ada ketidaksesuaian antara beban kerja dan jumlah pekerja. Untuk mengatasi masalah pengukuran beban kerja pada PPSDM Migas, maka dalam penelitian ini menggunakan pendekatan tugas per tugas. Metode ini akan memberikan informasi mengenai pengalokasian sumber daya manusia karyawan untuk menyelesaikan beban kerja yang ada secara optimal. Berdasarkan hasil pengukuran beban kerja pada PPSDM Migas dengan menggunakan pendekatan tugas per tugas dapat disimpulkan bahwa dari dua jabatan sebagai pilot project terdapat satu jabatan yang menghasilkan ketidaksesuaian antara beban kerja dengan jumlah pemangku jabatan yaitu pada jabatan Pelaksana Instalasi Tangki dan Distribusi memiliki jumlah pekerja sebanyak 4 pekerja namun dari hasil perhitungan dibutuhkan 7 pekerja. Jabatan Pelaksana Operasi Distilasi memiliki jumlah pekerja sebanyak 2 pekerja dan dari hasil perhitungan dibutuhkan 2 pekerja, hal ini menunjukkan kesesuaian antara jumlah pekerja dengan beban kerja pada jabatan tersebut. Berdasarkan hasil perhitungan dari kedua jabatan, jabatan Pelaksana Operasi Distilasi termasuk dengan kategori efisiensi jabatan cukup. Sedangkan pada jabatan Pelaksana Instalasi Tangki dan Distribusi mendapatkan kategori sedang.
\end{abstract}

Kata kunci : Analisis beban kerja; jumlah pekerja optimal; pendekatan tugas per tugas

\section{PENDAHULUAN}

Penelitian ini berfokus pada peningkatan produktifitas dalam perusahaan dengan penentuan jumlah pekerja yang optimal pada sebuah jabatan dengan menggunakan analisis beban kerja dengan pendekatan tugas per tugas. Permasalahan yang dihadapi oleh PPSDM Migas saat ini adalah banyaknya karyawan yang di mutasi dari PPSDM Cepu ke PPSDM Migas Pusat di Jakarta untuk pemenuhan pekerja di kantor pusat, akibat dari kebijakan ini adalah banyaknya karyawan lapangan yang dipindah kerjakan di kantor, oleh karena itu pekerja di lapangan 
menjadi lebih sedikit, hal ini menjadi masalah karena pekerjaan dilapangan sangatlah banyak sehingga di butuhkan jumlah pekerja yang mecukupi untuk melakukan pekerjaan di lapangan.

Salah satu upaya meningkatkan kapabilitas organisasi adalah dengan memastikan target kinerja selama periode kerja yang telah ditetapkan sesuai dengan kapabilitas organisasi. Untuk mengevaluasi kesesuaian antara target kinerja dengan kapabilitas organisasi, maka dapat dilakukan analisis beban kerja. Dengan adanya perhitungan beban kerja yang tepat, diharapkan dapat terjadi optimalisasi dan tercapainya target kinerja perusahaan selain itu pada saat melakukan penelitian ini perusahaan sedang terkena masalah terkait mutasi karyawan sehingga perlu dilakukan kajian ulang mengenai analisis beban kerja untuk menentukan jumlah pekerja optimal pada sebuah stasiun kerja.

Tujuan dari penelitian ini yaitu mengetahui beban kerja dari tiap karyawan dan menentukan jumlah karyawan dan tingkat efisiensi jabatan pada bagian operasi sarana penyelenggaraan diklat kilang. Batasan yang digunakan dalam penelitian ini adalah sebagai berikut ini:

1. Penelitian ini dilakukan dalam jangka waktu 1 Agustus 2017 - 31 Agustus 2017.

2. Penelitian dilakukan pada subbidang sarana prasarana pengembangan SDM dan informasi pada bagian operasi sarana penyelenggaraan diklat kilang.

3. Responden pada penelitian ini merupakan karyawan kantor PPSDM Migas yang dipilih sebagai pilot project sejumlah 2 jabatan .

4. Penentuan kebutuhan formasi dan tingkat efisiensi jabatan menggunakan metode Analisis Beban Kerja yang ditetapkan oleh Badan Kepegawaian Negara Indonesia berdasarkan Keppres No. 68 Tahun 1995.

\section{METODE PENELITIAN}

Teknik Perhitungan Beban Kerja yang digunakan dalam penelitian ini menggunakan metode yang telah ditetapkan oleh Badan Kepegawaian Negara Indonesia menurut Keppres No. 68 Tahun 1995. Analisis beban kerja dilakukan dengan membandingkan bobot/beban kerja dengan norma waktu dan volume kerja (Soeharto, 1995). Target beban kerja ditentukan berdasarkan rencana kerja atau sasaran yang harus dicapai oleh setiap jabatan, misalnya mingguan atau bulanan. Volume kerja datanya terdapat pada setiap unit kerja, sedangkan norma waktu hingga kini belum banyak diperoleh sehingga dapat dijadikan suatu faktor tetap yang sangat menentukan dalam analisis beban kerja. Penelitian ini menggunakan analisis beban kerja dengan pendekatan tugas per tugas

Pendekatan Tugas per Tugas adalah metode untuk menghitung kebutuhan pekerja pada jabatan yang hasil kerjanya abstrak atau beragam. Hasil beragam artinya hasil kerja dalam jabatan banyak jenisnya (Khomarudin, 1996). Informasi yang diperlukan untuk dapat menghitung dengan metoda ini adalah:

1. Uraian tugas beserta jumlah beban untuk setiap tugas

Uraian tugas pokok yang mencerminkan apa yang dikerjakan (what), bagaimana cara mengerjakan (how) dan mengapa dikerjakan (why).

2. Waktu penyelesaian rata-rata

Waktu rata-rata yang di ukur dari satuan waktu yang digunakan menyelesaikan suatu tugas jabatan yang di pengaruhi beberapa faktor, antara lain adalah perangkat kerja, kondisi lingkungan kerja, prosedur kerja, dan kompetensi pemegang jabatan.

3. Waktu Kerja Efektif (WKE)

Menurut Keppres No. 68 Tahun 1995 (Soeharto, 1995), ditetapkan bahwa :

Hari Kerja/Minggu

Satu Minggu

Jadi 1 Hari Jam Kerja

Allowance (Waktu Boros)

Pola 5 Hari Kerja :

Per Hari : 1 x 300 menit

Per Minggu : 5 x 300 menit

Per Bulan : 20 x 300 jam

$$
\begin{aligned}
& =37,5 \text { jam } \\
& =5 \text { hari } \\
& =37,5 \text { jam } / 5 \text { hari }=7,5 \text { jam/hari } \\
& =30 \% \\
& =300 \text { menit } \\
& =1.500 \text { menit } \\
& =6.000 \text { menit }
\end{aligned}
$$


Per Tahun : 240 x 300 menit Jam Efektif/Hari

4. Volume / Beban Kerja

Jumlah banyaknya satuan hasil kerja yang harus diselesaikan dalam waktu kerja efektif harian, mingguan, bulanan, atau tahunan.

a. Rumus Perhitungan Kebutuhan Jabatan

Perhitungan kebutuhan jabatan yang efektif adalah dianggap sangat mutlak diperlukan untuk membentuk struktur kerja yang efisien dan mampu membawa instansi meraih tujuan yang diharapkan. Rumus untuk menghitung perhitungan kebutuhan pekerja dengan pendekatan metoda tugas per tugas adalah (Menpan, 2004):

\section{$\sum$ Waktu Penyelesaian Rata-Rata x Beban Kerja \\ Waktukerja efektif}

b. Tingkat Efisiensi Jabatan

Suatu jabatan diperlukan standar tertentu untuk mengukur dan mengevaluasi apakah sudah termasuk sangat baik, baik, cukup, sedang, atau kurang. Berikut adalah rumus untuk menghitung tingkat efisiensi jabatan :

\section{¿Isi KerjaJabatan}

$\overline{\sum \text { Pemegang Jabatanx Waktu KerjaEfektif }}$

Berikut adalah standar Tingkat Efisiensi Jabatan:

A = sangat baik ; apabila TEJ $>1$

$\mathrm{B}=$ baik ; apabila TEJ $=0,90-0,99$

$\mathrm{C}=$ cukup ; apabila TEJ $=0,70-0,89$

$\mathrm{D}=$ sedang ; apabila $\mathrm{TEJ}=0,50-0,69$

$\mathrm{E}=$ kurang ; apabila TEJ $<0,50$

\section{HASIL DAN PEMBAHASAN}

\section{A. Job Description}

Pada tahap ini dilakukan pengambilan data yang digunakan utuk melakukan analisis beban kerja suatu jabatan. Data yang digunakan adalah data deskripsi tugas (Job Description) dan indikator kinerja yang didapat dari fungsi wawancara dan kuisioner. Deskripsi kerja dan indikator kinerja jabatan pelaksana operasi distilasi dan pelaksana instalasi tangki dapat dilihat pada Tabel 1. 
Tabel 1. Job description dan indikator kinerja jabatan pelaksana operasi distilasi

\begin{tabular}{|c|c|c|c|}
\hline No & Sub fungsi/ Jabatan & Job Description & Indikasi Kerja \\
\hline \multirow[t]{3}{*}{1.} & Pelaksana Operasi Distilasi & $\begin{array}{l}\text { 1. Pemantauan dibidang } \\
\text { pengembangan SDM } \\
\text { subsektor minyak dan } \\
\text { gas bumi }\end{array}$ & $\begin{array}{l}\text { 1. Berjalannya sistem } \\
\text { produksi dengan } \\
\text { baik dan lancar }\end{array}$ \\
\hline & & $\begin{array}{l}\text { 2. Penyelenggaraan } \\
\text { pendidikan dan } \\
\text { pelatihan di bidang } \\
\text { pengembangan SDM } \\
\text { subsektor minyak dan } \\
\text { gas bumi }\end{array}$ & $\begin{array}{l}\text { 2. Berjalannya } \\
\text { pembelajaran di } \\
\text { subsektor minyak } \\
\text { dan gas bumi dengan } \\
\text { baik dan lancar }\end{array}$ \\
\hline & & $\begin{array}{l}\text { 3. Pengelolaan sarana } \\
\text { prasarana teknis } \\
\text { pengembangan SDM } \\
\text { dan informasi subsektor } \\
\text { minyak dan gas bumi }\end{array}$ & $\begin{array}{l}\text { 3. Keadaan mesin yang } \\
\text { selalu terkendali } \\
\text { baik secara teknis } \\
\text { maupun fungsional }\end{array}$ \\
\hline \multirow[t]{4}{*}{2.} & $\begin{array}{l}\text { Pelaksana Instalasi Tangki } \\
\text { dan Distribusi }\end{array}$ & $\begin{array}{l}\text { 1. Koordinator keseluruhan } \\
\text { distribusi }\end{array}$ & $\begin{array}{l}\text { 1. Terlaksanakannya } \\
\text { segala kegiatan } \\
\text { distribusi dengan } \\
\text { baik }\end{array}$ \\
\hline & & 2. Branding Produk & $\begin{array}{l}\text { 2. Terciptanya produk } \\
\text { yang sesuai dengan } \\
\text { spesifikasi standar }\end{array}$ \\
\hline & & $\begin{array}{l}\text { 3. Pemrosesan Treating } \\
\text { Pertasol }\end{array}$ & 3. Pertasol baik \\
\hline & & $\begin{array}{l}\text { 4. System loading pertasol } \\
\text { ca cb cc }\end{array}$ & $\begin{array}{l}\text { 4. Loading berjalan } \\
\text { dengan baik }\end{array}$ \\
\hline
\end{tabular}

Data kedua yang digunakan adalah data jumlah pekerja pada jabatan yang diukur. Analisis perlu untuk mengetahui berapa jumlah pekerja yang menjabat pada jabatan terkait. Dengan itu diketahui pula jumlah pekerja yang memiliki deskripsi tugas dan aktivitas tugas yang sama. Berikut adalah jumlah pekerja yang menjabat pada jabatan:

1. Pelaksana Operasi Distilasi (2 pekerja)

2. Pelaksana Instalasi Tangki dan Distribusi (4 Pekerja) Sumber: PPSDM Migas

\section{B. Deskripsi Formulir Pemangku Jabatan}

Bagian ini menjelaskan mengenai formulir yang digunakan untuk mendapatkan data yang diperlukan untuk menganalisis beban kerja dari suatu jabatan. Formulir beban kerja diisi oleh pekerja dengan didampingi oleh analis. Pengisian formulir di lakukan bersamaan dengan wawancara terarah oleh analis. Gambar 1 dan Gambar 2 menunjukkan hasil rekap pengisian formulir beban kerja. 


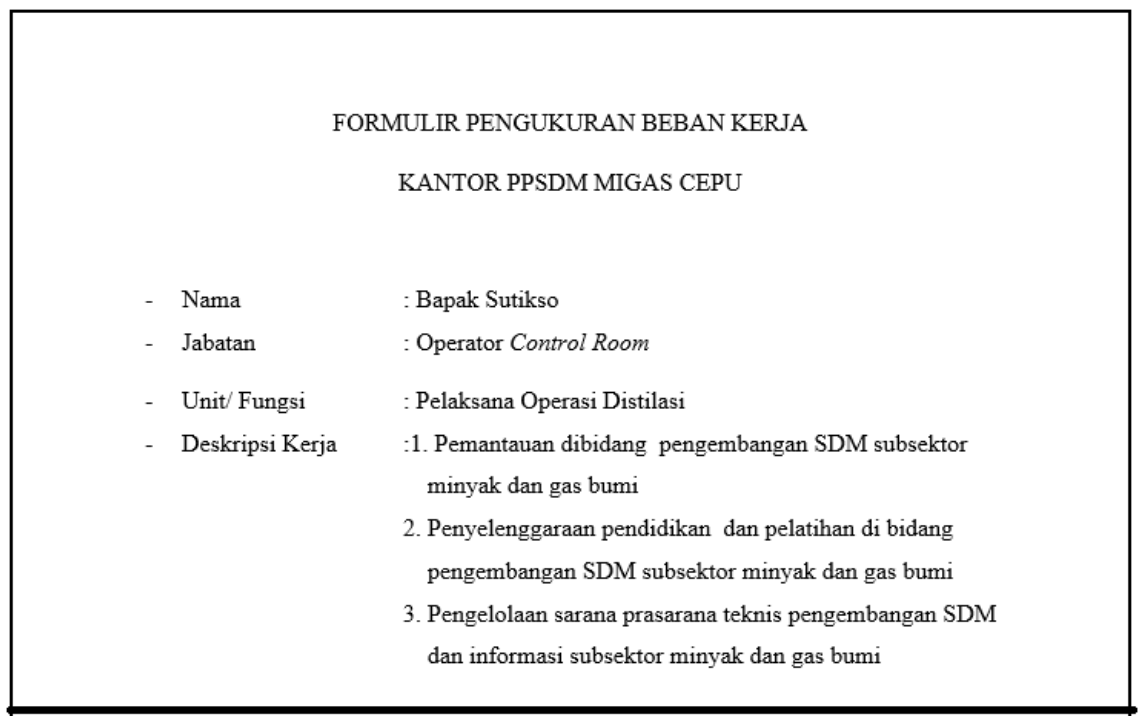

Gambar 1. Data diri pemangku jabatan pelaksana operasi distilasi

\begin{tabular}{|c|c|}
\hline \multicolumn{2}{|r|}{ FORMULIR PENGUKURAN BEBAN KERJA } \\
\hline & KANTOR PPSDM MIGAS CEPU \\
\hline \multirow[t]{2}{*}{ - Nama } & : Bapak Nurdin \\
\hline & Bapak Sigit \\
\hline \multirow[t]{2}{*}{ - Jabatan } & : Pelaksana distribusi \\
\hline & Operator pompa \\
\hline \multirow{7}{*}{$\begin{array}{ll}\text { - Unit/ Fungsi } \\
\text { - Deskripsi Kerja }\end{array}$} & : Pelaksana Instalasi Tangki dan Distribusi \\
\hline & 1. Koordinator keseluruhan distribusi \\
\hline & 2. Branding Produk \\
\hline & 3. Pemrosesan Treating Pertasol \\
\hline & 4. System loading pertasol $\mathrm{ca} \mathrm{cb} \mathrm{cc}$ \\
\hline & 5. Proses Receiving Crude Oil \\
\hline & 6. Additional \\
\hline
\end{tabular}

Gambar 2. Data diri pemangku jabatan pelaksana instalasi tangki dan distribusi

Pelaksanaan sampling interview pada jabatan Pelaksana Instalasi Tangki dan Distribusi dilakukan kepada dua orang. Pelaksanaan sampling harus mampu mewakili segala informasi dari setiap aktivitas pada jabatan tersebut.

\section{Deskripsi Formulir Pengukuran Beban Kerja Jabatan}

1. Jabatan Pelaksana Operasi Distilasi

Berdasarkan hasil pengambilan data menggunakan kuesioner dan wawancara yang dilakukan dengan jabatan Subbidang sarana prasarana pengembangan SDM dan Informasi bagian operasi sarana penyelenggaraan diklat kilang yaitu pelaksana operasi distilasi didapatkan hasil berupa 11 uraian tugas yang dilaksanakan yang dijelaskan pada Tabel 2. 
Tabel 2. Hasil rekap formulir bagian pengukuran beban kerja Jabatan pelaksana operasi distilasi

\begin{tabular}{|c|c|c|c|c|}
\hline No. & Uraian Tugas & Hasil Kerja & $\begin{array}{c}\text { Waktu } \\
\text { penyesuaian }\end{array}$ & Beban Kerja \\
\hline 1. & $\begin{array}{l}\text { Persiapan produksi di } \\
\text { lapangan }\end{array}$ & & 1 bulan & 7 mesin \\
\hline 2. & $\begin{array}{l}\text { Pengoperasian mesin DJS di } \\
\text { sistem pengendalian }\end{array}$ & Output data & $\begin{array}{l}8 \text { jam untuk } 5 \\
\text { sistem operasi }\end{array}$ & 5 komputer/ display \\
\hline 3. & $\begin{array}{l}\text { Melakukan input data } \\
\text { produksi untuk setiap shift }\end{array}$ & $\begin{array}{l}\text { Data } \\
\text { produksi }\end{array}$ & $\begin{array}{l}45 \text { menit untuk } \\
\text { sekali shift }\end{array}$ & 45 entry data \\
\hline 4. & $\begin{array}{l}\text { Melakukan orientasi bidang } \\
\text { kilang }\end{array}$ & Kegiatan & $\begin{array}{l}60 \text { menit dalam } \\
\text { sebulan }\end{array}$ & 3 \\
\hline 5. & $\begin{array}{l}\text { Melakukan orientasi produksi } \\
\text { dalam kilang }\end{array}$ & Kegiatan & $\begin{array}{l}60 \text { menit dalam } \\
\text { sebulan }\end{array}$ & 3 \\
\hline 6. & $\begin{array}{l}\text { Melakukan orientasi } \\
\text { laboratorium kilang }\end{array}$ & Kegiatan & $\begin{array}{l}60 \text { menit dalam } \\
\text { sebulan }\end{array}$ & 3 \\
\hline 7. & $\begin{array}{l}\text { Melakukan setting manual } \\
\text { mesin jika terjadi full } \\
\text { produksi minimal sekali } \\
\text { dalam sehari }\end{array}$ & & $\begin{array}{l}15 \text { menit dalam } \\
\text { sehari }\end{array}$ & 3 mesin \\
\hline 8. & $\begin{array}{l}\text { Melakukan setting suhu } \\
\text { manual pada mesin }\end{array}$ & & $\begin{array}{l}10 \text { menit per } \\
\text { mesin dalam } \\
\text { sehari }\end{array}$ & 7 mesin \\
\hline 9. & Kalibrasi pompa & Mesin baik & 30 menit/ bulan & 3 pompa \\
\hline 10. & Perbaikan mesin pompa & $\begin{array}{l}\text { Good } \\
\text { Machine }\end{array}$ & $\begin{array}{l}\text { Satu kali dalam } \\
\text { setahun }\end{array}$ & 1 mesin \\
\hline 11. & $\begin{array}{l}\text { Melakukan penyesuaian } \\
\text { mesin dengan display control }\end{array}$ & $\begin{array}{l}\text { Validasi } \\
\text { display } \\
\text { control }\end{array}$ & $\begin{array}{l}15 \text { menit dalam } \\
\text { sehari }\end{array}$ & \\
\hline
\end{tabular}

2. Jabatan Pelaksana Intalasi Tangki dan Distribusi

Berdasarkan hasil pengambilan data menggunakan kuesioner dan wawancara yang dilakukan dengan jabatan sub-bidang sarana prasarana pengembangan SDM dan Informasi bagian operasi sarana penyelenggaraan diklat kilang yaitu Pelaksana Intalasi Tangki dan Distribusi didapatkan hasil berupa 21 uraian tugas yang dilaksanakan. Tabel 3 menunjukkan hasil rekap kuesioner pengambilan data. 
Tabel 3. Hasil rekap formulir bagian pengukuran beban kerja Jabatan pelaksana operasi distilasi

\begin{tabular}{|c|c|c|c|c|}
\hline No. & Uraian Tugas & Hasil Kerja & Waktu penyesuaian & Beban Kerja \\
\hline 1. & Penerimaan minyak mentah & $\begin{array}{l}\text { Minyak } \\
\text { mentah }\end{array}$ & 4 hari sekali & 1 \\
\hline 2. & Treating sulfur pertasol & Pertasol & 7 jam dalam sehari & 4 pompa \\
\hline 3. & $\begin{array}{l}\text { Proses pengiriman barang/ } \\
\text { loading solar }\end{array}$ & Produk solar & 2 hari sekali & 1 \\
\hline 4. & Loading pertasol $\mathrm{ca} \mathrm{cb} \mathrm{cc}$ & $\begin{array}{l}\text { Produk } \\
\text { pertasol }\end{array}$ & Satu tangki 45 menit & 3 \\
\hline 5. & Pengawasan loading residu & & 7-10 hari & 7 \\
\hline 6. & Penyematan limbah & $\begin{array}{l}\text { Pemisahan } \\
\text { limbah }\end{array}$ & 3 jam dalam sehari & 1 \\
\hline 7. & Penggantian $\mathrm{NaOH}$ & $\mathrm{NaOH}$ & 1 jam dalam sehari & 1 \\
\hline 8. & Pemantauan Lapangan & & 5 jam dalam sehari & 1 \\
\hline 9. & Branding Produk & $\begin{array}{l}\text { Laporan } \\
\text { analisis }\end{array}$ & 3 kali dalam setahun & 3 \\
\hline 10. & Persiapan proses treating & & $\begin{array}{l}15 \text { menit dalam } \\
\text { sehari }\end{array}$ & 4 pompa \\
\hline 11. & $\begin{array}{l}\text { Pemrosesan penghilangan } \\
\text { impuritis dengan } \mathrm{NaOH}\end{array}$ & $\begin{array}{l}\text { Produk } \\
\text { Pertasol }\end{array}$ & 8 jam untuk 4 pompa & 4 pompa \\
\hline 12. & $\begin{array}{l}\text { Persiapan loading pertasol } \\
\text { ca cb cc }\end{array}$ & & $\begin{array}{l}15 \text { menit dalam } \\
\text { sehari }\end{array}$ & 1 \\
\hline 13. & $\begin{array}{l}\text { Proses loading pertasol ca } \\
\mathrm{cb} \text { cc }\end{array}$ & $\begin{array}{l}\text { Pertasol ca cb } \\
\text { cc }\end{array}$ & 1 tangki 45 menit & 3 \\
\hline 14. & $\begin{array}{l}\text { Pengukuran crude oil di } \\
\text { Pertamina EP }\end{array}$ & & 20 menit dalam 4 hari & 1 \\
\hline 15. & Proses analisa BSNW & & 40 menit dalam 4 hari & 1 \\
\hline 16. & Proses penerimaan crude oil & Crude Oil & 60 menit dalam 4 hari & 1 \\
\hline 17. & $\begin{array}{l}\text { Membantu proses loading } \\
\text { residu }\end{array}$ & Residu & 10 jam dalam sebulan & 1 \\
\hline 18. & Membantu shift & & 1 jam dalam sehari & 1 \\
\hline 19. & Orientasi Umum & Kegiatan & 1 jam dalam sebulan & 1 \\
\hline 20. & Stok Opname & Stok & 3 bulan sekali & 1 \\
\hline 21. & Kunjungan & Kegiatan & 3 bulan sekali & 1 \\
\hline
\end{tabular}

\section{Hasil Perhitungan Kebutuhan Pekerja}

Untuk menentukan kebutuhan pekerja yang dibutuhkan menggunakan metode Analisis Beban Kerja dengan pendekatan tugas per tugas digunakan rumus perhitungan (1). Setelah didapatkan waktu penyelesaian rata-rata, beban kerja dan waktu kerja efektif dari hasil rekap formulir pengukuran beban kerja, kemudian dilakukan perhitungan kebutuhan pekerja. Tabel 4 menunjukkan hasil perhitungan kebutuhan pekerja pada jabatan yang telah diukur. 
Tabel 4. Hasil perhitungan kebutuhan jabatan pelaksana operasi distilasi

\begin{tabular}{|c|c|c|c|c|}
\hline No. & Uraian Tugas & $\begin{array}{l}\text { Rata-rata } \\
\text { WP }\end{array}$ & $\begin{array}{c}\text { Waktu Kerja } \\
\text { Efektif }\end{array}$ & $\begin{array}{c}\text { Pegawai yang } \\
\text { dibutuhkan }\end{array}$ \\
\hline 1 & Persiapan produksi di lapangan & 3840 & 6000 & 0,64 \\
\hline 2 & $\begin{array}{l}\text { Pengoperasian mesin DJS di sistem } \\
\text { pengendalian }\end{array}$ & 300 & 300 & 1 \\
\hline 3 & $\begin{array}{l}\text { Melakukan input data produksi untuk } \\
\text { setiap shift }\end{array}$ & 45 & 300 & 0,15 \\
\hline 4 & Melakukan orientasi bidang kilang & 180 & 6000 & 0,03 \\
\hline 5 & $\begin{array}{l}\text { Melakukan orientasi produksi dalam } \\
\text { kilang }\end{array}$ & 180 & 6000 & 0,03 \\
\hline 6 & $\begin{array}{l}\text { Melakukan orientasi laboratorium } \\
\text { kilang }\end{array}$ & 180 & 6000 & 0,03 \\
\hline 7 & $\begin{array}{l}\text { Melakukan setting manual mesin jika } \\
\text { terjadi full produksi minimal sekali } \\
\text { dalam satu shift }\end{array}$ & 15 & 300 & 0,05 \\
\hline 8 & $\begin{array}{l}\text { Melakukan setting suhu manual pada } \\
\text { mesin }\end{array}$ & 70 & 300 & 0,2333 \\
\hline 9 & Kalibrasi pompa & 90 & 6000 & 0,015 \\
\hline 10 & Perbaikan mesin pompa & 6000 & 72000 & 0,0833 \\
\hline 11 & $\begin{array}{l}\text { Melakukan penyesuaian mesin } \\
\text { dengan display control }\end{array}$ & 15 & 300 & 0,05 \\
\hline \multicolumn{4}{|c|}{$\begin{array}{c}\text { Jumlah Pekerja yang } \\
\text { dibutuhkan }\end{array}$} & 2,31 \\
\hline
\end{tabular}

Dari perhitungan jumlah kebutuhan pekerja pada jabatan Pelaksana Operasi Distilasi didapatkan hasil sebesar 2.31 atau bisa dibulatkan menjadi 2 pekerja pada jabatan tersebut. Jumlah pekerja yang ada adalah 2 pekerja. Dari hasil perhitungan didapatkan jumlah kebutuhan pekerja sama dengan jumlah pekerja yang sudah ada. 
Tabel 5. Hasil perhitungan kebutuhan jabatan pelaksana instalasi tangki dan distribusi

\begin{tabular}{lllll}
\hline No. & \multicolumn{1}{c}{ Uraian Tugas } & $\begin{array}{c}\text { Rata-rata } \\
\text { WP }\end{array}$ & $\begin{array}{c}\text { Waktu Kerja } \\
\text { Efektif }\end{array}$ & $\begin{array}{c}\text { Pegawai yang } \\
\text { dibutuhkan }\end{array}$ \\
\hline 1 & Penerimaan minyak mentah & 300 & 6000 & 0,05 \\
2 & Treating sulfur pertasol & 420 & 300 & 1,4 \\
3 & $\begin{array}{l}\text { Proses pengiriman barang/loading } \\
\text { solar }\end{array}$ & 1200 & 1500 & 0,8 \\
4 & Loading pertasol ca cb cc & 135 & 1500 & 0,09 \\
5 & Pengawasan loading residu & 1260 & 6000 & 0,21 \\
6 & Penyematan limbah & 180 & 300 & 0,6 \\
7 & Penggantian NAOH & 60 & 300 & 0,2 \\
8 & Pemantauan lapangan & 300 & 300 & 1 \\
9 & Branding produk & 540 & 72000 & 0,0075 \\
10 & Persiapan proses treating & 60 & 300 & 0,2 \\
11 & Pemrosesan penghilangan impuritis & 480 & 300 & 1,6 \\
& dengan NaOH & & & \\
12 & Persiapan loading pertasol ca cb cc & 15 & 300 & 0,05 \\
13 & Proses loading pertasol ca cb cc & 135 & 300 & 0,45 \\
14 & Pengukuran di Pertamina EP & 100 & 6000 & 0,0167 \\
15 & Proses analisa BSNW & 200 & 6000 & 0,033 \\
16 & Menerima crude oil & 300 & 6000 & 0,05 \\
17 & Membantu proses loading residu & 600 & 6000 & 0,1 \\
18 & Membantu shift & 60 & 300 & 0,2 \\
19 & Orientasi umum & 60 & 6000 & 0,01 \\
20 & Stock opname & 1440 & 72000 & 0,02 \\
21 & Menerima kunjungan & 240 & 72000 & 0,0033 \\
\hline & $\quad$ Jumlah Pekerja yang & 7,090833 \\
& $\quad$ dibutuhkan & \\
\hline
\end{tabular}

Dari perhitungan jumlah kebutuhan pekerja pada jabatan Pelaksana Intalasi Tangki dan Distribusi didapatkan hasil sebesar 7,098 atau bisa dibulatkan menjadi 7 pekerja pada jabatan tersebut. Jumlah pekerja yang ada adalah 4 pekerja. Dari hasil perhitungan terdapat selisih antara jumlah kebutuhan pekerja dengan jumlah pekerja yang sudah ada yaitu sebesar 3 pekerja.

\section{E. Hasil perhitungan Tingkat Efisiensi Jabatan}

Untuk menentukan tingkat efisiensi jabatan pada pekerja menggunakan metode Analisis Beban Kerja dengan pendekatan tugas per tugas digunakan rumus perhitungan (2). Gambar 3 menunjukkan hasil konversi skor Tingkat Efisiensi Jabatan (TEJ) berdasarkan analisis beban kerja menggunakan pendekatan tugas per tugas.

\begin{tabular}{|c|c|c|c|c|c|}
\hline \multicolumn{6}{|c|}{ Standar Tingkat Efisiensi Jabatan (TEJ) } \\
\hline - & $A$ & $=$ sangat baik & apabila TEJ & $\geq$ & 1 \\
\hline - & $B$ & = baik & apabila TEJ & $=$ & $0,90-0,99$ \\
\hline - & C & $=$ cukup & apabila TEJ & $=$ & $0,70-0,89$ \\
\hline - & $\mathrm{D}$ & $=$ sedang & apabila TEJ & $=$ & $0,50-0,69$ \\
\hline - & $E$ & $=$ kurang & apabila TEJ & $<$ & 0,50 \\
\hline
\end{tabular}

Gambar 3. Standar tingkat efisiensi jabatan

Untuk mengetahui tingkat efisiensi jabatan maka diperlukan data total waktu penyelesaian rata-rata, data jumlah pekerja pada jabatan tersebut, dan data waktu kerja efektif selama satu 
tahun kerja. Berikut adalah perhitungan tingkat efisiensi jabatan Operasi Sarana Penyelenggaraan Diklat Kilang:

- $\quad \Sigma$ Waktu Penyelesaian rata-rata

- $\quad \Sigma$ Pemegang Jabatan

- Waktu Kerja Efektif

- Tingkat Efisiensi Jabatan

$$
\begin{aligned}
& =166440 \text { menit } \\
& =2 \text { pekerja } \\
& =72000 \text { menit } \\
& =166440 / 2 \times 72000=1,15
\end{aligned}
$$

Dari perhitungan tingkat efisiensi jabatan didapatkan skor sebesar 1,15. Apabila dikonversikan dengan Standar Tingkat Efisiensi Jabatan maka akan didapatkan hasil berada pada konversi nilai TEJ $>=1$ atau dapat dikategorikan bernilai "A" atau "sangat baik".

Untuk mengetahui tingkat efisiensi jabatan maka diperlukan data total waktu penyelesaian rata-rata, data jumlah pekerja pada jabatan tersebut, dan data waktu kerja efektif selama satu tahun kerja. Berikut adalah perhitungan tingkat efisiensi jabatan Operasi Sarana Penyelenggaraan Diklat Kilang :

- $\quad \Sigma$ Waktu Penyelesaian rata-rata

- $\quad \Sigma$ Pemegang Jabatan

- Waktu Kerja Efektif

$$
\begin{aligned}
& =510.540 \text { menit } \\
& =4 \text { pekerja } \\
& =72000 \text { menit } \\
& =510540 / 4 \times 72000=1,77
\end{aligned}
$$

- Tingkat Efisiensi Jabatan

Dari perhitungan tingkat efisiensi jabatan didapatkan skor sebesar 1,77. Apabila dikonversikan dengan Standar Tingkat Efisiensi Jabatan maka akan didapatkan hasil berada pada konversi nilai TEJ $>=1$. atau dapat dikategorikan bernilai "A" atau "sangat baik".

\section{SIMPULAN}

Berdasarkan hasil perhitungan dari dua jabatan sebagai pilot project terdapat satu jabatan yang menghasilkan ketidaksesuaian antara beban kerja dengan jumlah pemangku jabatan yaitu pada jabatan Pelaksana Instalasi Tangki dan Distribusi memiliki jumlah pekerja sebanyak 4 pekerja namun dari hasil perhitungan dibutuhkan 7 pekerja. Jabatan Pelaksana Operasi Distilasi memiliki jumlah pekerja sebanyak 2 pekerja dan dari hasil perhitungan dibutuhkan 2 pekerja, hal ini menunjukkan kesesuaian antara jumlah pekerja dengan beban kerja pada jabatan tersebut. Selain itu, dari penelitian ini dapat disimpulkan bahwa Pelaksana Operasi Distilasi termasuk dengan kategori efisiensi jabatan cukup. Sedangkan pada jabatan Pelaksana Instalasi Tangki dan Distribusi mendapatkan kategori sedang.

Dari kesimpulan diatas pada jabatan Pelaksana Instalasi Tangki dan Distribusi memiliki jumlah pekerja sebanyak 4 pekerja namun dari hasil perhitungan dibutuhkan 7 pekerja maka disarankan untuk melakukan penyesuaian, dapat dilakukan dari segi jumlah pekerja maupun dari segi beban kerja. Sementara untuk Jabatan Pelaksana Operasi Distilasi dirasa sudah sesuai dengan beban kerj jabatan tersebut. Selain itu, perlu dilakukan evaluasi berkala tentang perhitungan kebutuhan formasi jabatan di PPSDM Migas sebagai acuan untuk dilakukannya rotasi dan mutasi pekerja, serta penyesuaian target kerja dengan beban kerja yang dibebankan ke masing-masing jabatan. Hal lain yang perlu dilakukan adalah sosialisasi terlebih dahulu kepada fungsi yang akan diukur perhitungan beban kerja sebelum dilakukan perhitungan beban kerja.

\section{DAFTAR PUSTAKA}

Anggara. (2009). Tugas Akhir : Evaluasi Beban Kerja dan Optimalisasi Jumlah Karyawan Bagian Produksi Dengan Metode Work Load Analysis ( WLA ) Di PT. Sinar Djaja Can Gedangan-Sidoarjo. Surabaya : Teknik Industri, UPN Veteran Jatim.

Arsi., Partiwi. (2016). Tugas Akhir : Analisis Beban Kerja Untuk Menentukan Jumlah Optimal Karyawan Dan Pemetaan Kompetensi Karyawan Berdasar Pada Job Description. Surabaya: Teknik Industri, ITS.

Soeharto. (1995). Keppres No 68 Tahun 1995 tentang Hari Kerja Di Lingkungan Lembaga Pemerintah. Jakarta : Sekretariat Negara.

Lituhayu. M. (2008). Tugas Akhir Analisa Beban Kerja dan Kinerja Karyawan (Studi Kasus Pada Head Office PT. Lerindro International Jakarta). Bogor: Institut Pertanian Bogor. 